\begin{tabular}{c} 
Volume and Issues Obtainable at Center for Sustainability Research and Consultancy \\
Journal of Business and Social Review in Emerging Economies \\
ISSN: 2519-089X (E): 2519-0326 \\
Volume 5: No. 2, December 2019 \\
ᄃSRᄃ \\
Journal homepage: www.publishing.globalcsrc.org/jbsee \\
\hline
\end{tabular}

\title{
Performance Appraisal Systems in Hiram Hospital and Its Relationship With Employees' Performance: Empirical Study
}

\author{
${ }^{1}$ Zynab Badreddine, ${ }^{2}$ Malak Aoun \\ ${ }^{1}$ MBA Student, School of Business, Lebanese International University; Lebanon. \\ 30430245@students.liu.edu.lb \\ ${ }^{2}$ Assistant Professor, School of Business, Lebanese International University; Lebanon. \\ malak.aoun@liu.edu.lb
}

\begin{tabular}{l} 
ARTICLE DETAILS \\
\hline History \\
Revised format: November 2019 \\
Available Online:December 2019
\end{tabular}

Keywords

Performance, Hospital

JEL Classification:

P27, P29

\section{ABSTRACT}

Purpose: This study aims to investigate the relationship between different performance appraisal methods and employees' performance in a private hospital in South Lebanon. Three main appraisal methods were selected for this study including traditional appraisal, self-appraisal and customer appraisal methods. In addition, the employees' performance was measured at different levels including task, adaptive and contextual performance.

Design: Based on a quantitative approach and using self-administered questionnaires, primary data was collected randomly from 125 employees of the target hospital.

Findings: The results obtained showed that employees are generally performing in an adequate level and they are pleased with the current applied performance appraisal systems at this hospital and especially at the level of customer appraisal methods.

Originality: This study showed how private hospital in Lebanon use performance appraisal systems in managing their human resources through measuring employees' performance, motivating them and most commonly, making critical administrative decisions related to training and development or even rewarding and coercive actions.

Future suggestions: Future studies are recommended to expand the research geographically and comprise variety of hospitals in terms of size or type. Also, studying different performance appraisal systems would enrich the literature especially at the empirical level.

(C) 2019 The authors, under a Creative Commons AttributionNonCommercial 4.0

Corresponding author's email address: malak.aoun@liu.edu.lb

Recommended citation: Badreddine, Z. and Aoun, M. (2019). Performance Appraisal Systems in Hiram Hospital and its Relationship with Employees' Performance: Empirical Study. Journal of Business and Social Review in Emerging Economies, 5 (2), 275-286

DOI: $10.26710 /$ jbsee.v5i2.771

\section{Introduction}

Healthcare organizations and especially hospitals are compound associations which are liable to work movements and high employees' turnover. As per past investigations (Aiken et al., 2002; Jones, 2004; Mouro, 2012), the nature of hospitals can be contrarily impacted by the lack, turnover and poor performance of workers. Hence, it is fundamental to play out an effective performance appraisal to keep the certified workers and do essential preparing 
for the unqualified individuals. Agreeing El-Jardali (2009), the primary explanations behind employees' turnover in the Lebanese hospitals incorporate unacceptable pay rates and benefits, unsatisfactory shifts and working hours, better opportunities abroad, remaining task at hand, marriage and the geographical locations of hospitals. Subsequently, a well implemented performance appraisal system would uncover the hole between the authoritative guidelines and the requirements of workers and along these lines, improve their overall performance. Besides, numerous organizations normally use performance appraisal scores "to determine the distribution of pay, promotions, and other rewards; however, few organizations attempt to evaluate how employee perceptions of performance appraisal fairness impact employee attitudes and performance" (Swiercz et al., 2012).

Levinson (1976) stated that performance appraisal depends on three capacities. In the first place, it conveys pleasant feedback to every employee on his performance. Also, it acts as an establishment for changing behavior toward progressively better manners and third, it gives information to executives so they may pass judgment on future occupation activities and remuneration. The absence of talented employees confines the hospitals from creating and supporting upper hands and thus drives the hierarchical procedures to disappointment. Likewise, a few workers have acknowledged appraisal as only a straightforward routine exercise that has no centrality to their advancement, situation occupations and improvement for their preparation necessities accordingly having little impact on their advancement procedure.

Basically, the principle goal of this research is to determine to which degree is the performance appraisal systems applied in Hiram Hospital, South Lebanon. The second objective is to distinguish which is the best implemented performance appraisal method and third, to study the correlation between performance appraisal and employees' performance in this hospital.

\section{Literature Review}

\subsection{Employee Performance Definitions}

Employee performance means "individual's work achievement after exerting required effort on the job which is associated through getting a meaningful work, engaged profile, and compassionate colleagues/employers around" (Hellriegel et al., 1999; Karakas, 2010). Moreover, Pradhan et al. (2017) categorized employee performance into three levels including "task performance, adaptive performance and contextual performance".

\subsubsection{Task performance}

It comprises of "job explicit behaviors which includes fundamental job responsibilities assigned as a part of job description. Task performance requires more cognitive ability and is primarily facilitated through task knowledge, task skill and task habits" (Conway, 1999).

\subsubsection{Adaptive performance}

It is referred to the "individual's ability to adapt and provide necessary support to the job profile in a dynamic work situation is referred to as adaptive performance. Once employees originate a certain amount of excellence in their assigned responsibilities, they try to adjust their attitude and performance to the different requirements of their job. Moreover, adaptive performance is considered effective as it requires employees' capability in unstable work conditions" (Baard et al., 2014; Hesketh \& Neal, 1999).

\subsubsection{Contextual performance}

It is "a kind of pro-social behavior demonstrated by individuals in a work set-up. Such behaviors are expected of an employee but they are not mentioned in one's job description and it is performed with the intention of encouraging the progress of individual, group, or organization towards which it is directed" (Brief \& Motowidlo, 1986).

\subsection{Performance Appraisal}

As defined by Armstrong (2006), performance appraisal is the "the formal assessment and rating of individuals by their managers at specific intervals. In most organizations these evaluations are made either annually or semiannually". Meenakshi (2012) stated that "performance appraisal is not just about rating employees. Organizations carry out performance appraisal as a basis for administrative decisions such as promotion, allocation of financial rewards, employee development and identification of training needs". 
Conventionally, the workers' direct supervisors are the most rationale decision maker for assessing their performance". In any case, organizations are as of late looking for choices, for example, subordinates, companions and colleagues, self-evaluation, customer appraisal, and 360-degree feedback. Various techniques are characterized as following based on Mondy and Martocchro (2015) findings:

\subsubsection{Peer appraisal}

"It is reliable if the workgroup is stable over a reasonably long period of time and performs tasks that require considerable interaction".

\subsubsection{Self-appraisal}

"If individuals understand the objectives they are expected to achieve and the standards by which they are to be evaluated, so they are in the best position to appraise their own performance".

\subsubsection{Customer appraisal}

"Behavior of customers determines the degree of success a firm achieves".

Recently, organizations use the 360-degree feedback method. Rees and Porter (2003) express it as "a process that involves the key people in a person's network of working relationships making assessments of a person's performance. This may involve feedback from subordinates and any key outside parties, if it is practicable. It includes evaluation input from multiple levels within the firm as well as external sources".

\subsection{Previous Studies}

In reference to Kumar and Anjum (2011), they stated that "department heads, various medical committees and ultimately the board of directors are responsible for ensuring standards of medical care in hospitals". This is reliable with the perception of 360-degree feedback which states that "feedback on an employee's performance being provided by the manager, different people or departments an employee interacts with, external customers and the employee himself" (De Nisi \& Griffen, 2008). The traditional method that depends on evaluation by prompt directors is frequently time-constrained as a result of their duties and high outstanding burden. In any case, the peer appraisal method is deliberated as the most natural and satisfactory way to deal with hospital's employees (Kumar\& Anjum, 2011).

The impact of performance appraisal on worker inspiration was contemplated by Chaponda (2014) through "leading an overview among 300 employees in non-government organizations (NGO) in Nairobi". The researchers demonstrated that "different raters can increase the accuracy of performance evaluation, reduce bias, and increase employee's perceptions". Likewise, results demonstrated that administrators are able to address holes in workers' abilities which can significantly affect the employees' motivation. Furthermore, Poon (2004) studied the "effect of employees' perceptions of political motives in performance appraisal on their job satisfaction and intention to quit using survey data from an occupationally heterogeneous sample of 127 white collar employees from various organizations". The results of regression analysis demonstrate that employees were unsatisfied when they noticed a biased performance appraisal from their supervisors. This drove workers to resign. According to Kumar and Sinha (2011), "the performance of a health care professional may be appraised by the appropriate departmental manager, by other professionals in a team or program or by peers, based on prior agreement on expectations". They stated that appraisal methods may include "behavioral approaches such as rating scales, peer rating, ranking or nomination and outcome approaches such as management by objectives and goal setting". Also, they recommended that "professionals should give and receive timely feedback on a flexible schedule. Feedback can be provided one-onone, by a group assessing quality of care or through an anonymous survey".

Respectively, the following research framework is developed as shown in figure 1. 


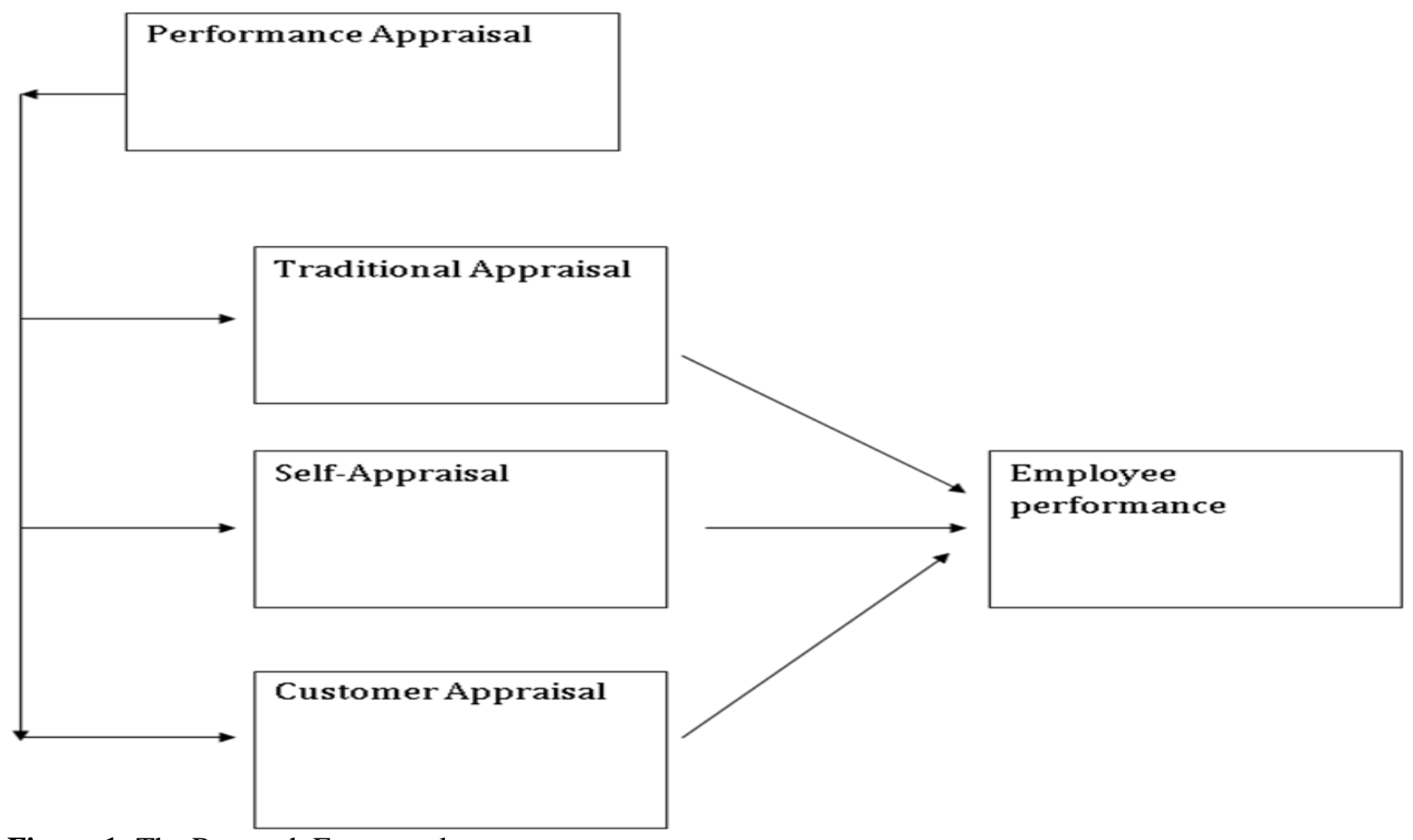

Figure 1: The Research Framework

To measure this research framework, the general hypothesis is developed as following:

H1: There is a significant and positive relationship between performance appraisal and employee performance. The sub-hypotheses include the relationship of three different performance appraisal methods with employee performance:

Ha: There is a significant and positive relationship between traditional appraisal and employee performance.

Hb: There is a significant and positive relationship between self-appraisal and employee performance.

Hc: There is a significant and positive relationship between customer appraisal and employee performance.

\section{Research Methodology}

This research has a positivism and deductive approach. It is based on quantitative methodology as it "provides valid answers, minimizes the risk of bias and it examines the relationship between variable by using numbers and statistics to explain and analyze its findings" (Burns et al, 1993). Both descriptive and correlational designs are applied to achieve the research objectives.

\section{Empirical Part}

\subsection{Population and Sample Size}

Hiram hospital is a private hospital in South Lebanon with a total 136 beds and 125 employees from diverse departments. In reference to Morgan's sample size table (1970), the best sample size for this survey is 80-108. Therefore, a sample size of 100 employees is considered sufficient for conducting this survey.

\subsection{Data Collection}

Primary data was collected over a short time horizon "10th May to 10th June 2019". Self-administered questionnaires were distributed randomly among employees. The questionnaire is structured into three key parts as shown in Appendix A. First part presents the respondents' demographic characteristics while the second part measures the employees' attitude on the current performance appraisal system in the hospital based on "5-Likert Scales: Strongly Disagree - Strongly Agree" (Fisher, 2004). Similarly, the third part measures the employees' performance in the hospital. 


\subsection{Data Analysis and Research Findings}

The data collected was analyzed using "SPSS software". The total average means of research variables are as following "employee performance (3.81), performance appraisal (3.36), traditional performance appraisal (4), selfappraisal (3.39) and customer appraisal (3.82)". Consequently, majority of respondents have shown an average agreement about the current implemented performance appraisal system in the hospital. As for the demographic statistics, table 1 summarizes the obtained results.

Table 1: Results for Demographic characteristics

\begin{tabular}{|l|l|}
\hline Demographic characteristics & Results \\
\hline Gender & $37 \%$ males \\
& $63 \%$ females \\
\hline Age & $41 \%$ 20-30 \\
& $40 \% 31-40$ \\
& $11 \% 41-50$ \\
& $8 \%$ above 50 \\
\hline Education & $67 \%$ employees (vocational degree) \\
& $6 \%$ High School \\
& $26 \%$ BBA \\
\hline Occupation & $1 \%$ MBA \\
\hline Years of experience & $90 \%$ nurses \\
& $7 \%$ administrative \\
& $3 \%$ technicians \\
\hline Length of service at current hospital & $48 \% 5-10$ years of experience \\
& $38 \%$ less than 5 years \\
& $14 \% 11-20$ years of experience \\
\hline
\end{tabular}

\subsection{Reliability and Validity of Data}

The next step was to measure the goodness of the measurement tool. Cronbach's alpha is greater than $0.7(0.744)$ for the 17 items. So, the reliability test showed "high consistency among the research variables". Moreover, the validity that is "the extent to which a measure correctly represents its corresponding construct" was detected using exploratory factor analysis (EFA). According to Hair et al., (2010), "The Kaiser-Meyer-Olkin (KMO) measure of sampling adequacy had to be more than 0.5 and the Bartlett's test of sphericity should show the significance of the validity at $\mathrm{p}<0.05$. Items having high loading factor should be deleted to increase the value of KMO above 0.5." Respectively, EP2, EP5, PA1, PA4, PA5 were deleted. Table 2 shows that all constructs have KMO values greater than 0.5 and "Bartlett's test of sphericity" are significant $(\mathrm{p}<0.05)$.

Table 2: EFA Results for Validity test

\begin{tabular}{|c|c|c|c|c|c|c|c|}
\hline \multirow{2}{*}{\multicolumn{2}{|c|}{ Constructs }} & \multirow{2}{*}{\multicolumn{2}{|c|}{$\begin{array}{l}\text { No. of } \\
\text { Items }\end{array}$}} & \multirow{2}{*}{ KMO } & \multicolumn{3}{|c|}{ Bartlett's Test of Sphericity } \\
\hline & & & & & Approx. $\chi^{2}$ & Df & Sig. \\
\hline \multirow[t]{3}{*}{ Performance Appraisal } & Traditional Appraisal & 2 & \multirow{3}{*}{6} & \multirow{3}{*}{0.685} & \multirow{3}{*}{77.570} & \multirow{3}{*}{10} & \multirow{3}{*}{0.000} \\
\hline & Self Appraisal & 1 & & & & & \\
\hline & Customer Appraisal & 3 & & & & & \\
\hline \multicolumn{2}{|l|}{ Employee performance } & \multicolumn{2}{|l|}{7} & 0.614 & 139.014 & 21 & 0.000 \\
\hline
\end{tabular}

\subsection{Testing Hypotheses}

\subsubsection{Correlation}

Table 3 below summarizes the results of correlation test. Performance appraisal and employee performance are significantly and positively correlated $(\mathrm{r}=0.440>0.3$ and $\mathrm{p}<0.01)$. Therefore, H1 is accepted. Also, the results showed that traditional appraisal method is significantly and positively correlated with employee performance 
$(\mathrm{r}=0.563, \mathrm{p}<0.01)$. Thus, Ha is accepted. Similarly, self-appraisal methods is significantly and positively correlated with employee performance $(\mathrm{r}=0.599, \mathrm{p}<0.01)$. Thus, $\mathrm{Hb}$ is accepted. For customer appraisal, the results showed a positive and significant correlation with employee performance and it is considered that highest correlation among all variables $(\mathrm{r}=0.703, \mathrm{p}<0.01)$. Hence, $\mathrm{Hc}$ is accepted.

Table 3: Pearson Correlations Results

\begin{tabular}{|ll|r|r|r|r|r|}
\hline & & TradiAP & CUSAP & SELFAP & AVEP & AVPA \\
\hline TradiAP & Pearson Correlation & 1 & $0.291^{* *}$ & 0.031 & $0.563^{* *}$ & $0.543^{* *}$ \\
& Sig. (2-tailed) & & 0.003 & 0.757 & 0.000 & 0.000 \\
& $\mathrm{~N}$ & 100 & 100 & 100 & 100 & 100 \\
\hline CUSAP & Pearson Correlation & $0.291^{* *}$ & 1 & $0.368^{* *}$ & $0.703^{* *}$ & $0.354^{* *}$ \\
& Sig. (2-tailed) & 0.003 & & 0.000 & 0.000 & 0.000 \\
& $\mathrm{~N}$ & 100 & 100 & 100 & 100 & 100 \\
\hline SELFAP & Pearson Correlation & 0.031 & $0.368^{* *}$ & 1 & $0.599^{* *}$ & 0.165 \\
& Sig. (2-tailed) & 0.757 & 0.000 & & 0.000 & 0.100 \\
& $\mathrm{~N}$ & 100 & 100 & 100 & 100 & 100 \\
\hline AVEP & Pearson Correlation & $0.563^{* *}$ & $0.703^{* *}$ & $0.599^{* *}$ & 1 & $0.440^{* *}$ \\
& Sig. (2-tailed) & 0.000 & 0.000 & 0.000 & & 0.000 \\
& $\mathrm{~N}$ & 100 & 100 & 100 & 100 & 100 \\
\hline AVPA & Pearson Correlation & $0.543^{* *}$ & $0.354^{* *}$ & 0.165 & $0.440^{* *}$ & 1 \\
& Sig. (2-tailed) & 0.000 & 0.000 & 0.100 & 0.000 & 100 \\
& $\mathrm{~N}$ & 100 & 100 & 100 & 100 & 100 \\
\hline
\end{tabular}

**. Correlation is significant at the 0.01 level (2-tailed).

\subsubsection{Regression Analysis}

The "multiple correlation coefficients (R) and the coefficient of multiple determinations R2" shown in Table 4 indicate that appraisal performance methods are explaining $79.4 \%$ of the employee performance variability.

Table 4: The Results of Model Summary

\begin{tabular}{|l|l|r|r|r|}
\hline Model & R & R Square & \multicolumn{1}{|c|}{$\begin{array}{c}\text { Adjusted R } \\
\text { Square }\end{array}$} & $\begin{array}{l}\text { Std. Error of } \\
\text { the Estimate }\end{array}$ \\
\hline 1 & $0.891^{\mathrm{a}}$ & 0.794 & 0.788 & 0.160 \\
\hline
\end{tabular}

a. Predictors: (Constant), SELFAP, TradiAP, CUSAP

In addition. Table 5 shows that appraisal performance significantly predict employee performance " $F(3,96)=$ 123.498 and $\mathrm{p}<0.01 \%$ 
Table 5: ANOVA Test

\begin{tabular}{|ll|r|r|r|r|c|}
\hline \multicolumn{2}{|c|}{ ANOVA $^{\mathbf{b}}$} \\
\hline Model & $\begin{array}{c}\text { Sum of } \\
\text { Squares }\end{array}$ & df & Mean Square & F & Sig. \\
\hline 1 & Regression & 9.429 & 3 & 3.143 & 123.498 & $0.000^{\mathrm{a}}$ \\
& Residual & 2.443 & 96 & 0.025 & & \\
& Total & 11.873 & 99 & & & \\
\hline
\end{tabular}

a. Predictors: (Constant), SELFAP, TradiAP, CUSAP

b. Dependent Variable: AVEP

\section{Conclusions}

Based on the obtained results, performance appraisal system is fairly practiced in Hiram hospital. As mention earlier, customer appraisal method got the highest correlation coefficient in relationship with employee performance. Therefore, employees are interested by the customers' effective feedback.

The research findings also revealed that employees know very well "what is expected from them to do in this hospital and they always inform their supervisor about all tasks they do as well". Nevertheless, employees are not accustomed yet with self-criticism attitude. Therefore, there should be training and development programs to help employees do self-appraisal and discuss with supervisors when necessary. Generally, results showed that from the employees' perspectives, patients are greatly satisfied from the employees' outstanding performance. Besides, there are complaints to management regarding any undesirable actions.

Despite of some limitations at the level of self-appraisal methods, this did not show a negative effect on the employee performance. The findings showed that majority of employees are performing in an outstanding level at "task, adaptive and contextual levels". Hence, employees are able to handle their tasks with least supervision and high quality standards as well. Moreover, the research findings showed that employees enjoy the current job flexibility at work. As for the level of contextual performance, employees did not show any problem to ask peers for help and they dynamically contribute in group-discussions as well as voluntary mentoring new colleagues.

\section{Recommendations}

This research has successfully achieved the proposed objectives. Thus, top managers in hospitals would benefit from such empirical studies to focus more on employee involvement, and inspire employees to apply self-criticism. The obtained results encourage appraisals to focus on a more comprehensive appraisal system such as the "360 degree feedback approach" that pools all internal and external appraisal methods. On the other hand, this study has some limitations at the level of population and sample size. The results reflected the status of current performance appraisal system at one hospital, therefore future studies are encouraged to enlarge the sample frame geographically, and use diversity of hospitals in terms of size and type. In addition, appraisal methods could be studied from different perspectives other than employees.

\section{References}

Cawley, B.D., Keeping, L.M. and Levy, P.E., 1998. Participation in the performance appraisal process and employee reactions: A meta-analytic review of field investigations. Journal of applied psychology, 83(4), p.615.

Chaponda, N.C., 2014. The effect of performance appraisal on employee motivation: a survey of slum based nongovernmental organizations in Nairobi (Doctoral dissertation, United States International UniversityAfrica).

DeNisi, A.S. and Pritchard, R.D., 2006. Performance appraisal, performance management and improving individual performance: A motivational framework. management and Organization Review, 2(2), pp.253-277.

Duarte, N.T., Goodson, J.R. and Klich, N.R., 1994. Effects of dyadic quality and duration on performance appraisal. Academy of Management journal, 37(3), pp.499-521.

Grote, R.C., 2002. The performance appraisal question and answer book: A survival guide for managers. AMACOM/American Management Association.

Hageman, M.G., Ring, D.C., Gregory, P.J., Rubash, H.E. and Harmon, L., 2015. Do 360-degree feedback survey 
results relate to patient satisfaction measures?. Clinical Orthopaedics and Related Research®, 473(5), pp.1590-1597.

Hofstede, G., 2001. Culture's consequences: Comparing values, behaviors, institutions and organizations across nations. Sage publications.

Jawahar, I.M. and Williams, C.R., 1997. Where all the children are above average: The performance appraisal purpose effect. Personnel Psychology, 50(4), pp.905-925.

Kikoski, J.F., 1999. Effective communication in the performance appraisal interview: Face-to-face communication for public managers in the culturally diverse workplace. Public personnel management, 28(2), pp.301-322.

Kumar, R. and Sinha, A., Employee performance appraisal in hospital: who, what, how and when? Indian Journal of Commerce \& Management Studies ISSN, 2229, p.5674.

Kuvaas, B., 2006. Performance appraisal satisfaction and employee outcomes: mediating and moderating roles of work motivation. The International Journal of Human Resource Management, 17(3), pp.504-522.

Mayer, R.C. and Gavin, M.B., 2005. Trust in management and performance: who minds the shop while the employees watch the boss?. Academy of management journal, 48(5), pp.874-888.

Meyer, J.P., Paunonen, S.V., Gellatly, I.R., Goffin, R.D. and Jackson, D.N., 1989. Organizational commitment and job performance: It's the nature of the commitment that counts. Journal of applied Psychology, 74(1), p.152.

Muczyk, J.P. and Gable, M., 1987. Managing sales performance through a comprehensive performance appraisal system. Journal of Personal Selling \& Sales Management, 7(1), pp.41-52.

Mwema, N.W. and Gachunga, H.G., 2014. The influence of performance appraisal on employee productivity in organizations: A case study of selected WHO offices in East Africa. International Journal of Social Sciences and Entrepreneurship, 1(11), pp.324-337.

Pearce, J.L. and Porter, L.W., 1986. Employee responses to formal performance appraisal feedback. Journal of applied psychology, 71(2), p.211.

Pettijohn, L.S., Stephen Parker, R., Pettijohn, C.E. and Kent, O.L., 2001. Performance appraisals: usage, criteria and observations. Journal of Management Development, 20(9), pp.754-771.

Poon, J.M., 2004. Effects of performance appraisal politics on job satisfaction and turnover intention. Personnel review, 33(3), pp.322-334.

Selden, S.C., Ingraham, P.W. and Jacobson, W., 2001. Human resource practices in state government: Findings from a national survey. Public Administration Review, 61(5), pp.598-607 Spinks, N., Wells, B. and Meche, M., 1999. Appraising the appraisals: Computerized performance appraisal systems. Career Development International, 4(2), pp.94-100..

Spinks, N., Wells, B. and Meche, M., 1999. Appraising the appraisals: Computerized performance appraisal systems. Career Development International, 4(2), pp.94-100.

Sudarsan, A., 2009. Performance appraisal systems: A survey of organizational views. The IUP Journal of Organizational Behaviour.

Twomey, D.F. and Harris, D.L., 2000. From strategy to corporate outcomes: Aligning human resource management systems with entrepreneurial intent. International Journal of Commerce and Management, 10(3/4), pp.4355.

Wise, R.R., Olson, A.J., Schrader, S.M. and Sharkey, T.D., 2004. Electron transport is the functional limitation of photosynthesis in field-grown Pima cotton plants at high temperature. Plant, Cell \& Environment, 27(6), pp.717-724. 
APPENDIX A

\section{Questionnaire}

\section{SECTION A: DEMOGRAPHICAL CHARACTERISTICS.}

Please identify your demographical characteristics by circling the appropriate number.

\begin{tabular}{llll}
\hline Gender & 1. Male & 2. Female \\
\hline Age 1$) 20-30$ & 2) $31-40$ & 3) $41-50$ & 4) above 50
\end{tabular}

Highest level of education

1. High School

5. MBA/MA/MS

2. BBA/BA/BS

6. MPH

3. $\mathrm{BSN}$

7. MD

4. BT/TS

8. Others. Please specify.................

Years of experience in healthcare organization
1) Below 5 years
2) $5-10$
3) $11-20$
4) Above 20 years

How long have you been working in this hospital?
1) $<5$ years
2) 5 - 10 years
3) $11-15$ years
4) $16-20$ years
5) $>20$ years

What is your occupational category?
1. Nurse
2. Administration
3. Physicians
4. Technician
5. Pharmacists
6. Others. Please specify:.......... 


\section{SECTION B: MEASUREMENT PERFORMANCE APPRAISAL}

From the statements listed below, please circle the number which best represents your opinion about the implemented performance appraisal systems in this hospital.

\begin{tabular}{|c|c|c|c|c|}
\hline Strongly Disagree & Disagree & Neutral & Agree & Strongly Agree \\
\hline 1 & 2 & 3 & 4 & 5 \\
\hline
\end{tabular}

\begin{tabular}{|c|c|c|c|c|c|c|}
\hline & Statements & SD & $\mathbf{D}$ & $\mathbf{N}$ & $\mathbf{A}$ & SA \\
\hline & Traditional appraisal & & & & & \\
\hline PAl & My direct supervisor evaluates my performance regularly & 1 & 2 & 3 & 4 & 5 \\
\hline PA2 & $\begin{array}{l}\text { My direct supervisor has enough time to evaluate my } \\
\text { performance }\end{array}$ & 1 & 2 & 3 & 4 & 5 \\
\hline \multirow[t]{2}{*}{ PA3 } & My direct supervisor shares evaluation results with me & 1 & 2 & 3 & 4 & 5 \\
\hline & Self-appraisal & & & & & \\
\hline PA4 & $\begin{array}{l}\text { I know very well what is expected from me to do in this } \\
\text { hospital }\end{array}$ & 1 & 2 & 3 & 4 & 5 \\
\hline PA5 & I criticize my own performance regularly & 1 & 2 & 3 & 4 & 5 \\
\hline \multirow[t]{2}{*}{ PA6 } & I inform my supervisor about all tasks I do in this hospital & 1 & 2 & 3 & 4 & 5 \\
\hline & Customer appraisal & & & & & \\
\hline PA7 & $\begin{array}{l}\text { Patients show their satisfaction from my good } \\
\text { performance }\end{array}$ & 1 & 2 & 3 & 4 & 5 \\
\hline PA8 & $\begin{array}{l}\text { Patients complaint to management about my poor } \\
\text { performance }\end{array}$ & 1 & 2 & 3 & 4 & 5 \\
\hline
\end{tabular}




\section{SECTION C: MEASUREMENT OF EMPLOYEE PERFORMANCE}

From the statements listed below, please circle the number which best represents your opinion about your own performance in this hospital.

\begin{tabular}{|c|c|c|c|c|}
\hline Strongly Disagree & Disagree & Neutral & Agree & Strongly Agree \\
\hline 1 & 2 & 3 & 4 & 5 \\
\hline
\end{tabular}

\begin{tabular}{|c|c|c|c|c|c|c|}
\hline & Statements & SD & D & $\mathbf{N}$ & $\mathbf{A}$ & SA \\
\hline & Task performance & & & & & \\
\hline EP1 & I use to maintain high standard of work & 1 & 2 & 3 & 4 & 5 \\
\hline EP2 & $\begin{array}{l}\text { I am capable of handling my assignments without much } \\
\text { supervision. }\end{array}$ & 1 & 2 & 3 & 4 & 5 \\
\hline \multirow[t]{2}{*}{ EP3 } & I am very passionate about my work & 1 & 2 & 3 & 4 & 5 \\
\hline & Adaptive performance & & & & & \\
\hline EP4 & $\begin{array}{l}\text { I could manage change in my job very well whenever } \\
\text { the situation demands }\end{array}$ & 1 & 2 & 3 & 4 & 5 \\
\hline EP5 & $\begin{array}{l}\text { I always believe that mutual understanding can lead to a } \\
\text { viable solution in organization }\end{array}$ & 1 & 2 & 3 & 4 & 5 \\
\hline \multirow[t]{2}{*}{ EP6 } & I am very comfortable with job flexibility & 1 & 2 & 3 & 4 & 5 \\
\hline & Contextual performance & & & & & \\
\hline EP7 & $\begin{array}{l}\text { I used to extend help to my co-workers when asked or } \\
\text { needed }\end{array}$ & 1 & 2 & 3 & 4 & 5 \\
\hline EP8 & $\begin{array}{l}\text { I actively participate in group discussions and work } \\
\text { meetings }\end{array}$ & 1 & 2 & 3 & 4 & 5 \\
\hline EP9 & $\begin{array}{l}\text { I use to guide new colleagues beyond my job } \\
\text { specialization }\end{array}$ & 1 & 2 & 3 & 4 & 5 \\
\hline
\end{tabular}


